\title{
IMPROVING PRODUCT DEVELOPMENT PERFORMANCE THROUGH KNOWLEDGE OUTSOURCING: A STUDY OF THE AUTOMOTIVE INDUSTRY IN IRAN
}

\author{
M. Mahdavi Mazdeh ${ }^{1}$, M. Jafari ${ }^{1}$, P. Akhaven ${ }^{2} \&$ S.J. Mousavi ${ }^{1 *}$
}

\section{ARTICLE INFO}

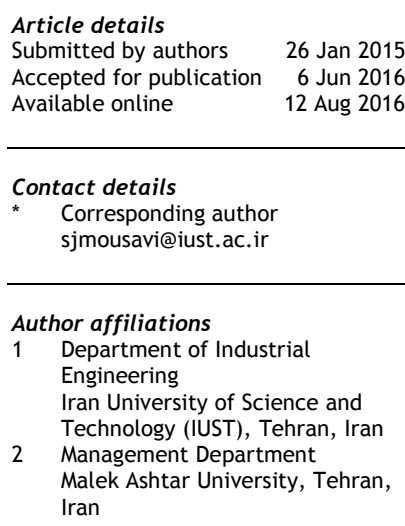

DOI

http://dx.doi.org/10.7166/27-2-1140

\section{ABSTRACT}

This study aims to explore the dynamics of the knowledge supply process for new product development in the automotive industry, and to evaluate the impact of knowledge outsourcing on new product development performance. The model was developed using a literature review and a multiple case study approach that looked at ten research and development companies from the automotive industry in Iran. The results indicate that knowledge outsourcing would improve new product development performance by increasing the flexibility of the new product development process to react to the environment's volatility, with few penalties in time and costs for automotive product development.

\section{OPSOMMING}

Die dinamiek van die voorkennisverkrygingsproses vir die ontwikkeling van nuwe produkte in die motorvoertuigindustrie word ondersoek om sodoende die impak van die uitkontraktering van die voorkennisverkryginsproses op die nuwe produkontwikkelingsproses te bepaal. Die voorgestelde model is ontwikkel deur ' $n$ literatuurstudie en deur van veelvoudige gevallestudies van motorvervaardigers in Iran gebruik te maak. Die resultate toon dat die uitkontraktering van die voorkennisverkryginsproses die produkontwikkelingsproses sal verbeter deur die aanpasbaarheid van die produkontwikkelingsproses by die mark se vlugtigheid te verhoog met weinige nadele, met betrekking tot die tyd en onkostes, wat van toepassing op die motor-voertuig produkontwikkelingsproses is.

\section{INTRODUCTION}

New product development (NPD) is one of the most knowledge-intensive fields of research and development [1]. Automotive organisations are technologically sophisticated [2, 3], and they have spent multiple millions of dollars to produce advanced knowledge, equipment, and products. Recognising the complexity of automotive products [3, 4], automotive organisations should create and develop a large amount of completely accurate and up-to-date knowledge [2, 5]. Management scholars have argued repeatedly that the development of innovative automotive products depends on the creation of new knowledge $[2,4,5]$. The underlying proposition is that the better a company is at creating knowledge, the more value it can deliver through generating superior products [6].

The rapidly-changing automotive industry faces high levels of competition [3,5]. NPD is a key process in the success, survival, and freshness of organisations in such industries. Because of the increased rate of product introductions, these organisations cannot efficiently create the required knowledge for NPD projects in-house, and therefore need to make use of the capabilities of other firms. Recognising this need, some of these organisations have begun to use external knowledge suppliers - from individual sectors of knowledge, to the whole subsystem development process - in order to improve their product development performance [5, 7]. Now new vehicles are developed and manufactured by original equipment manufacturers (OEM) and their network of suppliers, who often produce as much as 70 per cent of the value of a vehicle [5]. 
The trend of knowledge outsourcing in the automotive industry raises the question of its impact on NPD performance. Previous researchers have employed various NPD performance measures based on their different research purposes, with most variations of measurement focusing on NPD lead-time, NPD cost, NPD flexibility, and product quality [6, 8-13]. In order to analyse these measures of NPD performance, we need to understand the knowledge supply process better. However, the dynamics of knowledge supply for NPD have rarely been addressed in the literature. On the other hand, the development of automotive products has specific properties, such as dealing with complexity, traceability, awareness of the status of information, trust in knowledge, reliability, wide use of suppliers, severe competition, high development cost, long lead-times, high degree of knowledge intensity, rapidly changing technologies, and the inherent risks [2-5, 7]. So the dynamics of the knowledge supply process need to be analysed specifically for the automotive industry.

Iran's automotive industry was first developed in the 1960s, and relied on foreign vehicle manufacturers. Today the industry is growing dramatically, and has become Iran's second most active industry after the oil industry. The number of NPD projects and knowledge workers has also grown exponentially. Adopting appropriate policies in the area of supplying the knowledge required for NPD projects is the main issue facing the research and development companies if they are to produce the highest levels of performance amidst the economic fluctuations of the industry. The wide use of suppliers in Iran's automotive industry offers an interesting opportunity to examine empirically the knowledge supply process for new product development.

The first objective of this study was to identify the variables that influence the process of knowledge supply for NPD in the automotive industry, and to describe and formulate their behaviour as a system dynamics (SD) model. The second objective was to use the simulation results to evaluate the impact of knowledge outsourcing on the NPD performance measures. This paper could be viewed as one of the first to employ a simulation approach in examining knowledge supply chain behaviour based on the special characteristics of developing automotive products.

\section{LITERATURE REVIEW}

Several studies have discussed the creation of new knowledge as the central theme of the NPD process [1, 14-16]. Grant [14] considered the organisation as an institution in which individuals can transfer and integrate knowledge toward the creation of new knowledge, which in turn creates value in the form of new products. Madhavan and Grover [1] argued that new product development represents a reasonable proxy for new knowledge creation within the firm because it embodies that knowledge and the knowledge creation process. They suggested that the entire new product development process could be viewed as one of embodying new knowledge in a product. Similarly, Armbrecht et al. [15] argued that NPD is the creation of new knowledge.

Jakubik [17] showed that the focus of knowledge creation has shifted to inter-firm collaborations. He identified four distinct phases of knowledge management $(K M)$. The first phase focused on the outcomes of knowledge creation, on the knowledge of things, on data processing, and on information technology (IT). In the second phase, KM focused on the organisational knowledge creation process [18]. In the late 1990s the focus turned to the sources and enabling conditions of knowledge creation [18]. The contribution of Nonaka et al. [19] to knowledge creation theory integrates the knowledge creation process $(\mathrm{SECl})$ with the place and with the enabling conditions. In the recent discourse of $\mathrm{KM}$, which started in the early 2000s, the focus has shifted from knowledge creation within a firm to inter-firm collaboration [17] and toward knowledge supply chains [20-22].

Knowledge supply chain, first proposed in 1995 by the Next-Generation Manufacturing Project (NGMP) of America, is oriented by customer demand and connecting knowledge providers, innovators, and users through knowledge innovation to realise the network structure mode of knowledge economisation, global optimisation, and profit maximisation [21]. The concept of knowledge supply chain stems from the theory of supply chain management. In the 21st century knowledge has increasingly become the focus of the supply chain, and has become one of the most important elements of production, along with logistics, capital flow, and other physical resources [20]. Xiuhong [22] defined knowledge supply chain as a knowledge-based supply chain that takes the 'knowledge circuit' as the main line, connects the nodes of knowledge supply, innovation, dissemination, and application through a knowledge demand and supply relationship, converts ideas into knowledge-bearing products, and offers them to the end user [22]. Existing knowledge supply chain research mainly focuses on the aspect of definitions and theoretical study or applied research. 
However, the core purpose of the construction of the knowledge supply chain is knowledge creation and innovation, and to foster the conversion of scientific and technological achievements [23].

While analysing existing approaches to the interrelationships of knowledge creation, supply chain, and NPD, 25 variables that influence the process of knowledge supply for NPD (as indicated in Table 1) and three research streams were identified:

1. Aligning new product development and new knowledge creation;

2. Shifting the focus from knowledge creation within a firm to inter-firm collaboration; and

3. Developing the concept of the knowledge supply chain.

Table 1: Variables extracted from the literature that influence the process of knowledge supply for NPD

\begin{tabular}{|l|l|l|}
\hline Code & Variables & References \\
\hline L1 & Knowledge suppliers & {$[9,22,23]$} \\
\hline L2 & Knowledge network & {$[13,24]$} \\
\hline L3 & Knowledge workers & {$[6,9,22,23]$} \\
\hline L4 & R\&D capacity & {$[25]$} \\
\hline L5 & Knowledge integration & {$[26]$} \\
\hline L6 & Knowledge creation capability & {$[11]$} \\
\hline L7 & Knowledge supply/creation & {$[8,24]$} \\
\hline L8 & SECl's modes of knowledge creation & {$[6]$} \\
\hline L9 & Knowledge demand & {$[20,23]$} \\
\hline L10 & Knowledge absorption ability & {$[11,23]$} \\
\hline L11 & Knowledge stock/Existing knowledge & {$[8,11,23,26,27]$} \\
\hline L12 & Prior experience & {$[29]$} \\
\hline L13 & Knowledge transfer to the organisation & {$[8,24,26]$} \\
\hline L14 & Knowledge management & {$[23]$} \\
\hline L15 & Information technology & {$[9]$} \\
\hline L16 & Knowledge application & {$[23]$} \\
\hline L17 & Researchers' scientific quality & {$[27]$} \\
\hline L18 & R\&D financial resources & {$[9,29]$} \\
\hline L19 & Knowledge outsourcing cost & {$[8,22]$} \\
\hline L20 & Knowledge workers' cost (Salary and overheads) & {$[22]$} \\
\hline L21 & Subsystems' supply cost & {$[8]$} \\
\hline L22 & Product quality (NPD performance measure) & {$[6,8,9,11]$} \\
\hline L23 & NPD cost (NPD performance measure) & {$[6,8,9,11]$} \\
\hline L24 & NPD lead-time/Project progress rate (NPD performance measure) & {$[6,8,9,11]$} \\
\hline L25 & NPD flexibility (NPD performance measure) & {$[6,8,9,11]$} \\
\hline & & \\
\hline
\end{tabular}

We want to contribute to these streams of research by developing a model that explains the dynamics of knowledge supply for NPD, and by analysing the impact of knowledge outsourcing on NPD performance in the automotive industry.

In this research, a system dynamics approach was chosen to develop the model for the following reasons:

a) Automotive products are complex systems, and many variables and relationships should be considered when analysing the process of knowledge supply for developing them.

b) Useful historical data are available in the case companies about the influencing variables, the behavioural patterns of which can be used in modelling and analysing the process.

c) The study aims to analyse the dynamics of the process over a period of time rather than presenting a snapshot.

d) Policy-making on knowledge outsourcing is an objective of the study.

e) The causal relations should be known in order to analyse the process.

Using SD to model the process of new product development (NPD) is favoured by researchers because of its complexity and uncertainty [28, 29]. However, no dynamic model of NPD that deals with knowledge creation in a knowledge supply chain was found in the literature. 
A system dynamics approach was adopted in this study. The key variables influencing the knowledge supply process of NPD were identified using the literature, case studies, and the experts' opinions. Given the history of the variables' behavioural patterns, the causal structure of knowledge supply was determined, which consists of positive and negative relationships between variables, feedback loops, system archetypes, and delays [30]. Based on the causal structure, the simulation model was then created. This step includes the identification of stock and flow diagrams. Stock represents accumulated quantities, whereas flow controls the changing rate of quantity going into or out of stock [30]. Vensim ${ }^{\circledR}$ PLE software was used to construct the model. The validity of the model was checked through structural and behavioural tests such as dimensional consistency, extreme conditions, pattern reproduction, and statistical evaluation tests [30]. Lastly, policy analysis was conducted to analyse the impact of the knowledge outsourcing policy on NPD performance.

\subsection{Case studies}

The selection of case companies was critical for the research because we sought to investigate the knowledge creation process within companies with a successful track record of using a knowledge supply chain for new product development. For this reason, we adopted a purposive sampling strategy and selected ten companies from the automotive industry in Iran. The selected companies generate most of their revenue from new product development, and have made significant progress in the last decade in developing their knowledge supply chains. They are from different hierarchical levels of automotive product development and from a wide range of engineering fields. Table 2 provides details of the companies that were involved in the research.

Table 2: Overview of the involved companies

\begin{tabular}{|c|c|c|c|c|c|c|c|c|}
\hline \multirow[t]{2}{*}{ Code } & \multirow[t]{2}{*}{ Companies } & \multirow{2}{*}{$\begin{array}{l}\text { Product } \\
\text { hierarchy } \\
\text { level }\end{array}$} & \multirow{2}{*}{$\begin{array}{l}\text { Engineering } \\
\text { fields }\end{array}$} & \multicolumn{5}{|c|}{ The respondents and the duration of interviews (min) } \\
\hline & & & & $\begin{array}{l}\text { Chief } \\
\text { executive } \\
\text { officers }\end{array}$ & \begin{tabular}{|l}
$\begin{array}{l}\text { Chief } \\
\text { design } \\
\text { officers }\end{array}$ \\
\end{tabular} & \begin{tabular}{|l|} 
Project \\
managers
\end{tabular} & \begin{tabular}{|l} 
Knowledge \\
workers
\end{tabular} & $\begin{array}{l}\text { No. of } \\
\text { interviews }\end{array}$ \\
\hline Co1 & OWDI & System & $\begin{array}{l}\text { Mechanical, } \\
\text { Electronic, } \\
\text { Materials }\end{array}$ & 80 & 91 & 90 & 79 & 4 \\
\hline Co2 & MLHR & System & $\begin{array}{l}\text { Mechanical, } \\
\text { Electronic, } \\
\text { Materials }\end{array}$ & & 92 & 59 & 93 & 3 \\
\hline Co3 & MRM & $\begin{array}{l}\text { Subsystem } \\
\text { - First } \\
\text { Level }\end{array}$ & $\begin{array}{l}\text { Mechanical, } \\
\text { Materials }\end{array}$ & 95 & & 72 & 65 & 3 \\
\hline Co4 & DHRG & $\begin{array}{l}\text { Subsystem } \\
\text { - Second } \\
\text { Level }\end{array}$ & Chemical & 64 & 65 & 74 & 88 & 4 \\
\hline Co5 & SSTGR & $\begin{array}{l}\text { Subsystem } \\
\text { - First } \\
\text { Level }\end{array}$ & $\begin{array}{l}\text { Mechanical, } \\
\text { Materials }\end{array}$ & 57 & 88 & 89 & 74 & 4 \\
\hline Co6 & XRM & $\begin{array}{l}\text { Subsystem } \\
\text { - First } \\
\text { Level }\end{array}$ & \begin{tabular}{|l|} 
Electronic, \\
Electromechanical
\end{tabular} & 64 & 57 & 75 & 65 & 4 \\
\hline Co7 & PUR & $\begin{array}{l}\text { Subsystem } \\
\text { - First } \\
\text { Level }\end{array}$ & $\begin{array}{l}\text { Mechanical, } \\
\text { Chemical, } \\
\text { Materials }\end{array}$ & & 70 & 90 & 62 & 3 \\
\hline Co8 & IDI & $\begin{array}{l}\text { Subsystem } \\
\text { - Second } \\
\text { Level }\end{array}$ & $\begin{array}{l}\text { Electronic, } \\
\text { photonic }\end{array}$ & 80 & & 73 & 83 & 3 \\
\hline Co9 & $\mathrm{OHD}$ & $\begin{array}{l}\text { Subsystem } \\
\text { - Second } \\
\text { Level }\end{array}$ & Electronic & & 71 & 95 & 73 & 3 \\
\hline Co10 & BMRMN & $\begin{array}{l}\text { Subsystem } \\
\text { - Second } \\
\text { Level }\end{array}$ & $\begin{array}{l}\text { Materials, } \\
\text { Mechanical }\end{array}$ & 72 & 79 & 66 & 94 & 4 \\
\hline
\end{tabular}

\subsection{Qualitative data}

Semi-structured interviews were conducted with NPD managers and experienced knowledge workers in order to gain better insight into the automotive knowledge supply chain for NPD, to discuss the variables extracted from the literature, and to identify influencing variables that were not extracted 
from the literature. The interviewees included 11 chief executive officers, 12 project managers, and 12 knowledge workers with experience in NPD projects. Table 2 provides details of the 35 interviews that were conducted. Each interview lasted around 85 minutes and covered the following issues: details of the company, new product development process, knowledge supply chain structure, knowledge required for new product development, knowledge supply processes, knowledge outsourcing, internal knowledge creation, and influencing variables extracted from the literature. The sessions were recorded and analysed to extract information on the issues of interest to the researchers.

\subsection{Quantitative data}

Actual data of OWDI, one of the main research and development companies of the Iranian automotive industry, were used to simulate the model and analyse the results. OWDI develops products at the system level. Over the 25-year history of OWDI the number of NPD projects and knowledge workers has grown exponentially.

A review of relevant documents, site visits, and experts' opinions was used to gather quantitative data and also to triangulate the responses obtained during the interviews.

\subsection{The experts}

An expert group helped to identify the key variables of the model, to validate results, and to generate data in cases where there were insufficient archival documents. This expert group was composed of three representatives from OWDI (top managers of the departments of R\&D, HRM, and financial management) and two academics from the Iran University of Science and Technology (from the fields of knowledge management, supply chain management, and manufacturing management). The Delphi technique was used to obtain consensus among the experts. Opinions and comments from the experts were incorporated into every step of the study in order to validate the outputs (e.g., causal structures, simulation model, and policy recommendations). That is, the outputs could not be accepted as valid without agreement among the experts.

\section{MODEL DEVELOPMENT}

\subsection{Identifying the key variables}

The key variables influencing the described knowledge supply process were identified in three steps: from a literature review, case studies, and experts' opinions. In the first step, 25 influencing variables were identified using a literature review, as indicated in Table 1 . In the second step, 25 influencing variables were identified using data collected from the case studies (via interviews, a review of documents, and site visits), as indicated in Table 3. Variables extracted from the literature were discussed during the interviews.

Table 3: Variables that influence the process of knowledge supply for NPD, extracted from the case studies

\begin{tabular}{|l|l|l|l|}
\hline Code & Variable & Code & Variable \\
\hline C1 & External researchers & C14 & NPD project progress rate \\
\hline C2 & Internal researchers & C15 & Number of developed products \\
\hline C3 & Knowledge supply capacity & C16 & New needs of customers \\
\hline C4 & Knowledge creation capacity & C17 & R\&D fund \\
\hline C5 & Doing knowledge work & C18 & Knowledge outsourcing cost \\
\hline C6 & SECl's modes of knowledge creation & C19 & Salary and overheads cost \\
\hline C7 & Defining knowledge work & C20 & Subsystems supply cost \\
\hline C8 & Prior experience & C21 & System implementation cost \\
\hline C9 & Existing knowledge & C22 & Product quality (NPD performance measure) \\
\hline C10 & Knowledge management & C23 & NPD cost (NPD performance measure) \\
\hline C11 & External researchers' efficiency & C24 & NPD lead-time (NPD performance measure) \\
\hline C12 & Internal researchers' efficiency & C25 & NPD flexibility (NPD performance measure) \\
\hline C13 & Defining NPD projects & & \\
\hline
\end{tabular}

In the third step, the experts' opinions were used in a Delphi panel to identify the key variables of the model. All variables in Tables 1 and 3 (37 variables, repetitions excluded) were presented to the experts, and they were asked to approve or modify the variables list and give their reasons. Agreement by all the experts was the criterion for the approval or rejection of each variable. In 
each round of Delphi, the modified variables list and the reasons were presented to the experts. The Delphi panel was conducted in three rounds to achieve full consensus.

- In the first round, among the 37 listed variables, 11 were approved, 14 were rejected, and 12 were not agreed upon. Six new or alternative variables were also introduced.

- In the second round, among the 29 listed variables, 17 were approved, 10 were rejected, and two were not agreed upon. One new or alternative variable was also introduced.

- In the third round, among the 20 listed variables, 18 were approved, and two were rejected. No new or alternative variable was introduced. Thus full consensus was achieved.

Table 4 shows the identified key variables for the model.

Table 4: The model's key variables

\begin{tabular}{|l|l|l|l|}
\hline Code & Variable & Code & Variable \\
\hline V1 & External knowledge suppliers & V11 & New needs of customers \\
\hline V2 & Internal knowledge suppliers & V12 & R\&D financial resources \\
\hline V3 & Knowledge supply/creation capacity & V13 & Knowledge outsourcing cost \\
\hline V4 & Knowledge supply/creation & V14 & Salary and overheads cost \\
\hline V5 & Knowledge demand & V15 & Subsystems' supply cost \\
\hline V6 & Knowledge stock/ Existing knowledge & V16 & System implementation cost \\
\hline V7 & Knowledge management & V17 & NPD project progress rate \\
\hline V8 & Knowledge supply/Creation efficiency & V18 & NPD cost (NPD performance measure) \\
\hline V9 & Defining NPD projects & V19 & NPD lead-time (NPD performance measure) \\
\hline V10 & Number of developed products & V20 & NPD flexibility (NPD performance measure) \\
\hline
\end{tabular}

\subsection{Developing causal structure and simulation model}

Using the identified key influencing variables and the history of their behavioural patterns, the causal structure of the knowledge supply process of NPD was developed, as shown in Figure 1. The causal relationships between the variables can be described based on the reinforcing and balancing loops as follows:

- $\quad$ Reinforcing loop 1: New product creates new needs and expectations from customers, which leads to the need to define more new product development projects and more new products.

- $\quad$ Reinforcing loops 2 and 3: As the NPD project progresses, the budget is released and the R\&D financial resources increase. The knowledge supply capacity can then be increased by employing internal and external knowledge suppliers, accelerating the NPD projects, developing new products in shorter time, and allocating more budgets to R\&D.

- Reinforcing loop 4: By supplying/creating more knowledge, the knowledge stock is enriched, and knowledge suppliers can become more efficient by using experiences, lessons learned, documents, and other implicit and explicit knowledge resources. Thus the knowledge supply/creation capacity increases.

- $\quad$ Balancing loops 5 and 6: As the number of knowledge suppliers increases, costs and overheads increase, leading to greater use of R\&D's financial resources. The costs of internal knowledge suppliers include salary and overheads such as office space, equipment, and utility charges, and the costs of external knowledge suppliers include contract costs and overheads of monitoring.

The simulation model was developed based on the causal structure, as shown in Figure 2 . The loops correspond to each of the six designed loops of the causal structure and are given the same labels. Corresponding variables and relations have also been shown using bold text and thick arrows.

\subsection{Model validation}

The model's validity was assessed through structural and behavioural tests. Structural validation tests whether the model is a meaningful description of the real relations, while behavioural validation compares the behaviour patterns generated by the model with real-life data. The validation tests were conducted as follows, based on Sterman [30].

\subsubsection{Structural validation}

The structural validity of the model in respect of the appropriateness of its boundary, variables, relationships, parameters, and equations was checked throughout the modelling process by using inputs from the literature, the case studies, and the experts' opinions. Additionally, the model was 
reassessed repeatedly by the experts. Dimensional consistency of the equations was tested by the software. During the simulation, the extreme conditions test was also performed to assess whether the model responds reasonably when subjected to extreme input values. Overall, it was concluded that the model is structurally valid.

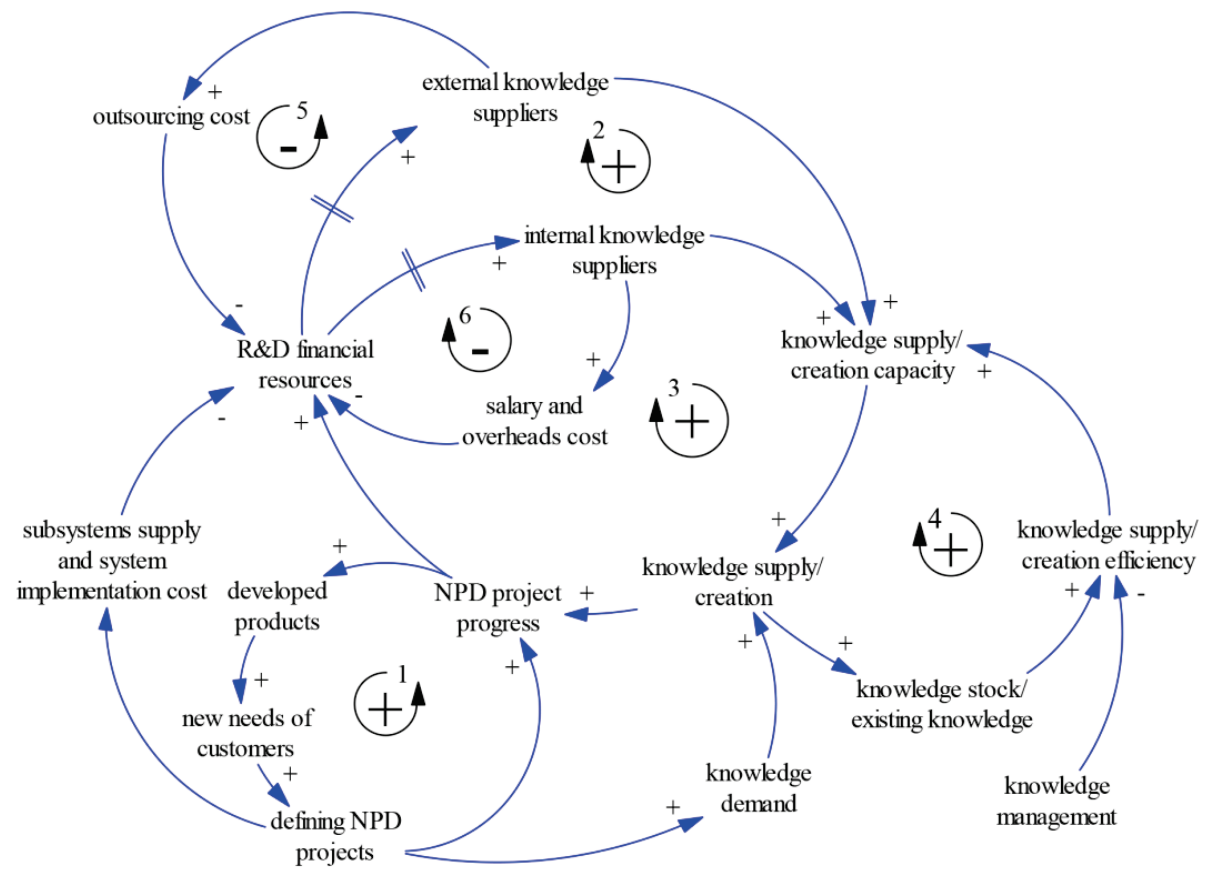

Figure 1: The causal structure of the knowledge supply process of NPD

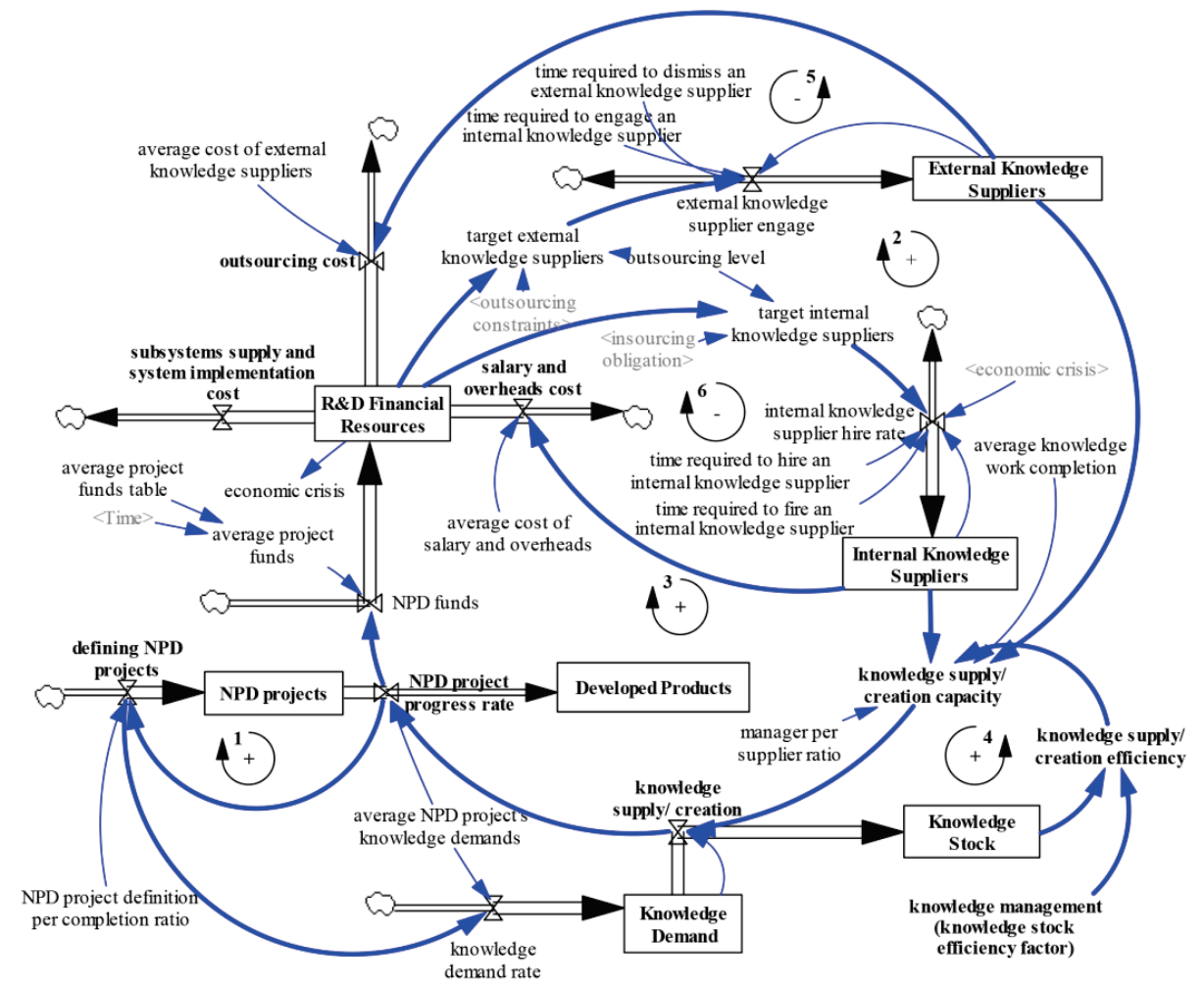

Figure 2: The simulation model of the knowledge supply process of NPD 


\subsubsection{Behaviour validation}

It is crucial to note that the emphasis of behavioural validation is on pattern prediction rather than on point prediction. This is a logical result of the long-term policy orientation of SD models [30]. The pattern reproduction test was conducted to compare graphical or visual measures of the most typical behavioural characteristics, such as the amplitude of a peak time between two peaks, and the number of inflection points. For instance, Figure 3 indicates the actual data and simulation results of the 'developed products' and 'internal knowledge suppliers' variables respectively from 1989 to 2014. The simulation reveals that the values of the variables comply with real-life behaviour. Furthermore, for statistical evaluation of the model behaviour, root mean square percentage error (RMSPE) and Nash-Sutcliffe coefficient $\left(E_{n s}\right)$ were used. Statistical results also indicated that the model complies with the data.
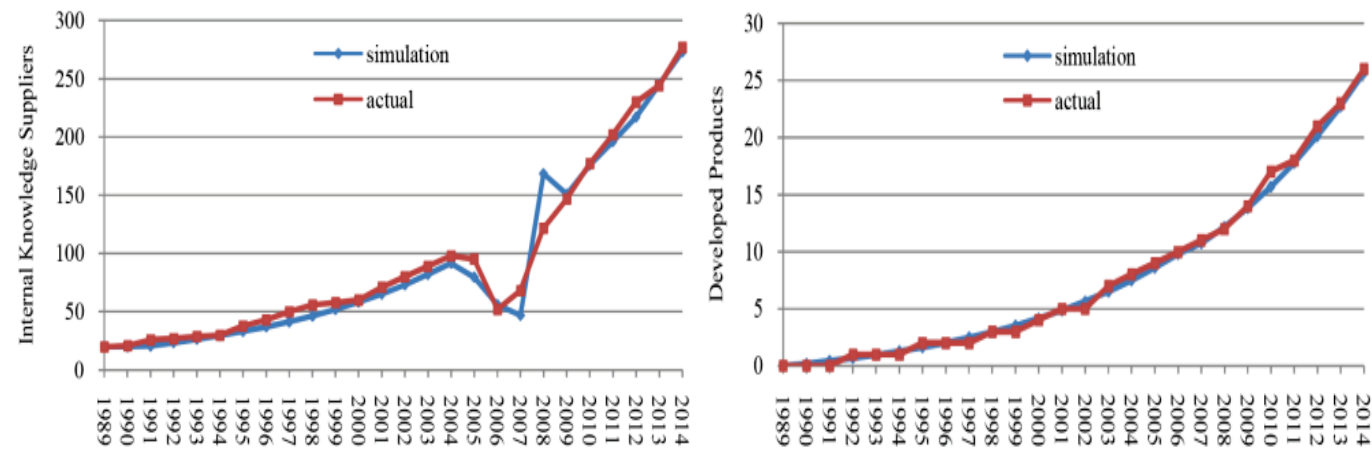

Figure 3: Comparisons of the model base run and historical data of the 'developed products' variable

\section{5}

RESEARCH RESULTS

So far the model has been shown to be structurally and behaviourally valid. This section aims to analyse the impact of knowledge outsourcing policy on improving new product development performance using actual data from OWDI.

\subsection{NPD performance measures}

To analyse the model, it is necessary to determine NPD performance measures. The following measures were indicated, based on the literature, the case studies, and the experts' opinions, as described in Section 4.1:

- NPD lead-time: It measures how long it takes OWDI to develop a new product. The average time of product development was regarded as the indicator of this measure, which is calculated by dividing the total time of simulation by the total developed products.

- $\quad$ NPD cost: It measures how much OWDI has to spend to develop a new product. The average cost of the product development life cycle was taken as the indicator of this measure, which is calculated by dividing the total costs of R\&D during the simulation period (including subsystems supply, system implementation, knowledge outsourcing, and internal knowledge suppliers' costs) by the total developed products.

- $\quad$ NPD flexibility: It measures the ability of OWDI to reconfigure resources and activities quickly in response to environmental demands. The average ratio of variable resources was taken as the indicator of this measure, which is calculated by dividing the variable costs of R\&D (including subsystems supply, system implementation, and knowledge outsourcing) by its total costs, during the simulation period.

\subsection{Policy analysis for knowledge outsourcing}

The R\&D financial resources were explored to analyse the flexibility of OWDI to manage resources to adapt quickly to market fluctuations and changes in the environment. From late 2004 to mid2007, the R\&D financial resources were negative, as seen in Figure 4 ('current' diagram). Figure 4 also shows the comparisons of model runs for different levels of outsourcing. It indicates that the 
R\&D financial resources could always be positive for outsourcing levels of 60 per cent. Another point to note in the chart is that the higher level of outsourcing reduces the volatility of R\&D financial resources.

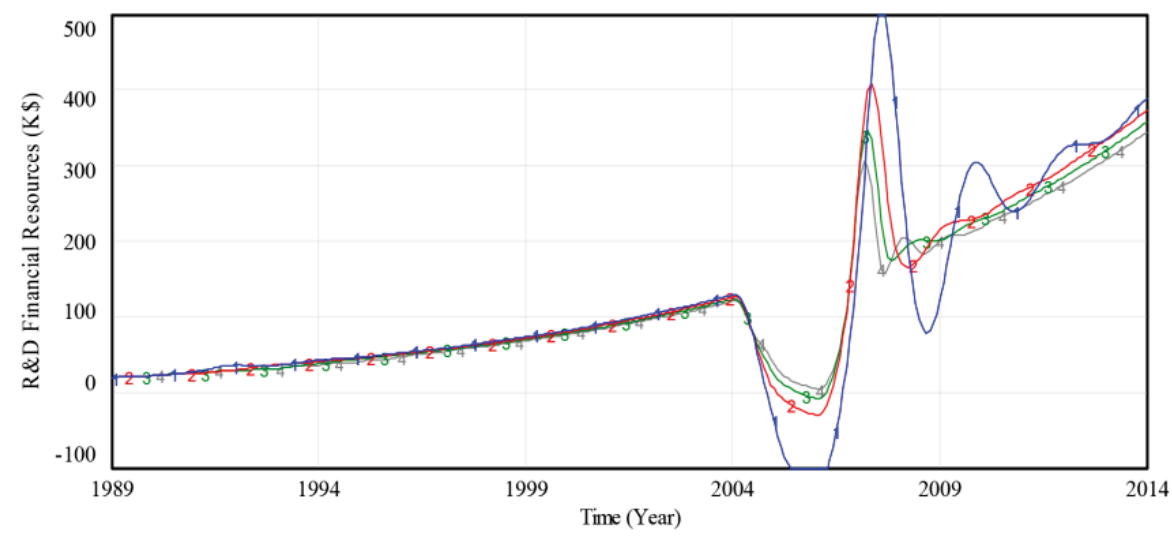

"R\&D Financial Resources" : $15 \%$ outsourcing (current)

"R\&D Financial Resources" : $30 \%$ outsourcing 2

"R\&D Financial Resources" : $45 \%$ outsourcing
"R\&D Financial Resources" : $60 \%$ outsourcing

Figure 4: The R\&D financial resources for different levels of outsourcing (see online version for colour figure)

The number of developed products was investigated to analyse the new product development leadtime. Figure 5 shows the various levels of outsourcing in different runs of the model. As shown in Figure 5 , by increasing the outsourcing level to 60 per cent, the number of developed products decreases from 25 ('current' diagram) to 24 .

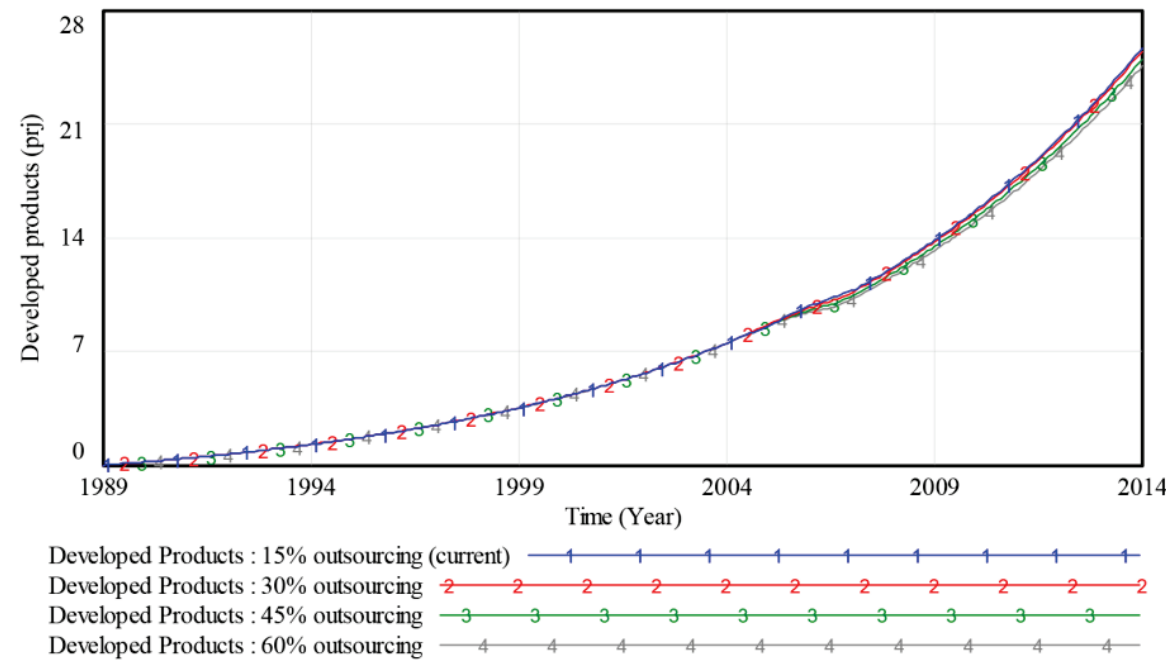

Figure 5: The number of developed products for different levels of outsourcing (see online version for colour figure)

Ultimately, we examined the values of the measures of new product development performance for different levels of outsourcing. As seen in Table 5, an increase in the level of knowledge outsourcing to 60 per cent increases the NPD flexibility by 33 per cent, while the lead-time and costs of product development are increased by 4 per cent and 1 per cent respectively.

The results indicate that knowledge outsourcing policy would significantly increase the NPD flexibility of OWDI to react to market volatility with little penalty in the lead-time and cost of product development. Thus OWDI can use this policy to improve its NPD performance. Detailed analysis of the simulation results indicates that, if the market fluctuations follow the past 25-year 
Table 5: The values of NPD performance measures for different levels of outsourcing

\begin{tabular}{|l|l|l|l|}
\hline Level of outsourcing (\%) & NPD lead-time (Month) & NPD cost (K\$) & NPD flexibility (\%) \\
\hline 15 (current) & 11.7 & 2377 & 57 \\
\hline 30 & 11.8 & 2385 & 64 \\
\hline 45 & 12.0 & 2394 & 70 \\
\hline 60 & 12.2 & 2401 & 76 \\
\hline
\end{tabular}

trend, then the optimised level of knowledge outsourcing would be 55 per cent, in order to keep the R\&D financial resources always positive, with minimal lead-time and cost of new product development. This level was recommended to OWDI as a target for knowledge outsourcing policy.

\section{6}

DISCUSSION

This study showed that using the policy of knowledge outsourcing with a slight increase in cost and lead-time can significantly increase the flexibility of new product development and thereby improve NPD performance.

Significant increase in NPD flexibility. Outsourcing turns fixed costs into variable costs and leads to flexibility in costs. By modelling the NPD's knowledge supply process, it was observed that NPD costs can be managed well by knowledge outsourcing. Iran's automotive industry is one of the top industries of the country in terms of technology and knowledge, and is also faced with international sanctions. So the required knowledge and technology cannot be bought from within the country or from other countries that are industry leaders. So developing new products in the automotive industry relies heavily on new knowledge creation. Flexibility in NPD costs is highly dependent on flexibility in the volume of knowledge workers, because NPD's main fixed costs are the knowledge workers' salaries and overheads. Flexibility in the volume of knowledge workers can be acquired by using external knowledge suppliers because (a) the process of contracting can be quick, (b) they are normally specialists in their particular area and do not require much training time, and (c) the contracts can be short-term. Thus the automotive companies can turn fixed labour costs into variable costs by using a knowledge outsourcing strategy, and can enhance the ability to manage the economic risks associated with new product development by managing the variable costs. They can also acquire flexibility in other dimensions of new product development, such as flexibility in functions and structure.

Slight increase in NPD cost. Due to the complexity and high technological level of automotive products, only a few research institutes have the necessary expertise and experience to provide the required knowledge for NPD. As a result, these institutes are usually expensive to use, which leads to the higher costs of outsourced knowledge activities. This situation is exacerbated in Iran by the sanctions and by limited access to international sources of automotive knowledge and technology. On the other hand, in addition to the costs of training employees, salary, and overheads, creating knowledge internally has a huge cost of trial-and-error activities. Considering the uncertainties in the research process and the high cost of testing automotive products, there are many experiences in the case companies where internal knowledge creation has been made possible only at very high cost. Therefore, greater cost for knowledge supply from reliable sources rather than through internal knowledge creation is justified. In the long term, knowledge outsourcing will increase the range of knowledge suppliers, leading to a competitive environment and reduced costs.

Slight increase in NPD lead-time. Due to intense competition, there is constant pressure to reduce product development time, which usually leads to insufficient focus on the concept development and feasibility study phases of NPD, and therefore the lack of a precise technical specification of knowledge activities. The time of outsourced knowledge activities is usually increased due to lack of mutual understanding and continuous control, which causes rework. By proactively managing the knowledge outsourcing process, the automotive companies can ensure that the outputs meet their time and quality requirements. The automotive companies must define the problem clearly enough before knowledge outsourcing, so as to avoid deviation from technical specification and time schedules by carefully and constantly monitoring the activity after starting the outsourced knowledge activity. 
The first aim of this study was to develop a system dynamics model to explore the dynamics of the knowledge supply process of NPD in the automotive industry. The model was developed and simulated using inputs from relevant literature, case studies, and expert opinion. Its validity was analysed and approved through structural and behavioural tests such as dimensional consistency, extreme conditions, pattern reproduction, and statistical evaluation tests. For example, the root mean square percentage error and Nash-Sutcliffe coefficient of the key variables were in the acceptable range (RMSPE $<3.5$ and $E_{n s}>0.93$ ). We can conclude, therefore, that the developed model can be used to describe and evaluate the behaviour of the knowledge supply process of NPD.

Another aim of the study was to evaluate the impact of knowledge outsourcing on NPD performance. Flexibility, cost, and lead-time of the NPD process were identified as measures of NPD performance, and were analysed for various levels of outsourcing in different runs of the model. By increasing the level of knowledge outsourcing from 15 per cent to 60 per cent, NPD flexibility was increased by 33 per cent, while the lead-time and cost of product development were increased by 4 per cent and 1 per cent respectively. So, using the results of the simulation, we can conclude that knowledge outsourcing would improve NPD performance by increasing the flexibility of the NPD process to react to market volatility with little penalty in either time or the cost of automotive product development.

This research is of value not only in facilitating better understanding of the knowledge supply behaviour of NPD, but also in assisting automotive managers to achieve improved NPD performance by using knowledge outsourcing policy. Furthermore, it might be viewed as one of the first to use a simulation approach to examine knowledge supply dynamics, based on the special characteristics of developing automotive products. The paper has studied the knowledge supply process, mainly from the perspective of resource allocation, and not in terms of its effectiveness. Further studies are needed to explore the effectiveness of relationships with knowledge suppliers and their impact on NPD performance. While this study has developed in the automotive industry, the applicability of its findings to other industries also needs further research.

\section{REFERENCES}

[1] Madhavan, R. \& Grover, R. 1998. From embedded to embodied knowledge: New product development as knowledge management. Journal of Marketing, 62(4), pp. 1-12.

[2] Pillania, R. 2008. Creation and categorization of knowledge in automotive components SMEs in India. Management Decision, 46(10), pp. 1452-1463.

[3] Sanchez, A.M. \& Perez, M.P. 2005. Supply chain flexibility and firm performance: A conceptual model and empirical study in the automotive industry. International Journal of Operations and Production Management, 25(7), pp. 681-700.

[4] De Massis, A., Lazzarotti, V., Pizzurno, E. \& Salzillo, E. 2012. Open innovation in the automotive industry: A multiple case-study. In: Sun, H. (ed.) Management of technological innovation in developing and developed countries. Rijeka, Croatia: InTech, pp. 217-236.

[5] Dyer, J.H. \& Nobeoka, K. 2000. Creating and managing a high-performance knowledge-sharing network: The Toyota case. Strategic Management Journal, 21(3), pp. 345-367.

[6] Schulze, A. \& Hoegl. M. 2006. Knowledge creation in new product development projects. Journal of Management Studies, 32(2), pp. 210-236.

[7] Akhavan, P., Behin, E. \& Jafari, M. 2014. A new integrated knowledge model in supplier selection: The case of an Asian automotive supply chain. Education, Business and Society: Contemporary Middle Eastern Issues, 7(4), pp. 333-368.

[8] Kanat, S. \& Atilgan, T. 2014. Effects of knowledge management on supply chain management in the clothing sector: Turkish case. Fibres \& Textiles in Eastern Europe, 22(1), pp. 9-13.

[9] Hilletofth, P. \& Eriksson, D. 2011. Coordinating new product development with supply chain management. Industrial Management \& Data Systems, 111(2), pp. 264-281.

[10] Buganza, T., Dell'Era, C. \& Verganti, R. 2009. Exploring the relationships between product development and environmental turbulence: The case of mobile TLC services. Journal of Product Innovation Management, 26(3), pp. 308-321.

[11] Smith, K.G., Collins, C. \& Clark, K.G. 2005. Existing knowledge, knowledge creation capability, and the rate of new product introduction in high-technology firms. Academy of Management Journal, 48(2), pp. 346-357.

[12] Larso, D. 2004. Manufacturing flexibility in new product development: Perceptions and implications of new product performance. Doctoral Dissertation, Oregon State University, Corvallis, OR.

[13] Tatikonda, M.V. \& Rosenthal, S.R. 2000. Successful execution of product development projects: Balancing firmness and flexibility in the innovation process. Journal of Operations Management, 18(4), pp. 401-425. 
[14] Grant, R.M. 1996. Prospering in dynamically-competitive environments: Organizational capability as knowledge integration. Organization Science, 7(4), pp. 375-387.

[15] Armbrecht. F.M.R., Chapas, R.B., Chappelow, C.C., Farris, G.F., Friga, P.N. , Hartz, C.A., Mcllvaine, M.E., Postle, S.R. and Whitwell, G.E. 2001. Knowledge management in research and development. Research Technology Management, 44(4), pp. 28-48.

[16] Thamhain, H.J. 2003. Managing innovative R\&D teams. R\&D Management, 33(3), pp. 297-311.

[17] Jakubik, M. 2008. Experiencing collaborative knowledge creation processes. The Learning Organization, 15(1), pp. 5-25.

[18] Nonaka, I. \& Konno, N. 1998. The concept of 'Ba': Building a foundation for knowledge creation. California Management Review, 40(3), pp. 40-54.

[19] Nonaka, I., Reinmoeller, P. \& Senoo, D. 2000. Integrated IT systems to capitalize on market knowledge. In: Von Krogh, G., Nonaka, I., Nishiguchi, T. (eds) Knowledge creation: A source of value. London: Macmillan Press, pp. 89-109.

[20] Ying, W. \& Wei-Wei, J. 2010. The study on enhancing the structured capability of enterprise knowledge management based on the theory of knowledge supply chain. 2010 International Conference of Information Science and Management Engineering (ISME), pp. 337-340.

[21] Zhong, L. 2010. The research of the development strategy of library knowledge management based on knowledge supply chain. 2010 International Conference on E-Product E-Service and E-Entertainment (ICEEE), pp. 1-4.

[22] Kok, R.A.W. \& Ligthart, P.E.M. 2014. Differentiating major and incremental new product development: The effects of functional and numerical workforce flexibility. Journal of Product Innovation Management, 31(S1), pp. 30-42.

[23] Zhang, G., Xie, X. \& Wang, Y. 2006. On the knowledge supply chain model of enterprise human resources on bionics. 2006 International Conference on Service Systems and Service Management, pp. 791-797.

[24] Wei, H.L. \& Ju, P.H. 2010. Dimensions of social capital and supply chain knowledge creation: The mediating role of learning information exchange. 2010 International Conference on Computers and Industrial Engineering (CIE), pp. 1-5.

[25] Kanscheck, K., Meisner, D., Kieb, K. \& Mercer, D. 1998. A modeling approach for university-industry relations. Conference on Academic and Industrial Cooperation in Space Research, pp. 23-30.

[26] Bumenberg, S., Wagner, H. \& Beimborn, D. 2009. Knowledge transfer process in IT outsourcing relationships and their impact on shared knowledge and outsourcing performance. International Journal of Information Management, 29(1), pp. 342-352.

[27] Giuliani, E. \& Arza, V. 2009. What drives the formation of 'valuable' university-industry linkages? Insights from the wine industry. Research Policy, 38(1), pp. 906-921.

[28] Wang, K.J., Lee, Y.H., Wang, S. \& Chu, C.P. 2009. Performance evaluation of resource allocation strategies for new product development under different workload scenarios. Journal of Modelling in Management, 4(2), pp. 91-113.

[29] D’Avino, G., Dondo, P., Lo Storto, C. \& Zezza, V. 2005. Reducing ambiguity and uncertainty during new product development: A system dynamics based approach. Portland International Conference on Management of Engineering and Technology, pp. 538-549.

[30] Sterman, J.D. 2000. Business dynamics: Systems thinking and modeling for a complex world. New York, NY: McGraw-Hill. 